Proceedings

\title{
Agricultural Diversity of Kashmir Valley
}

\author{
Shabir A. Zargar ${ }^{1 *}$, Tajamul Islam ${ }^{1}$ and Junaid A. Margay ${ }^{1}$
}

1 Department of Botany, University of Kashmir, Srinagar-190006, J \& K, India

*Corresponding author e-mail: shabirzargar786@gmail.com

† Presented at the 1st International Electronic Conference on Biological Diversity, Ecology and Evolution, 1531 March 2021; Available online: https://bdee2021.sciforum.net/.

Citation: Shabir A. Zargar, Tajamul Islam and Junaid A. Margay. Agricultural Diversity of Kashmir Valley. Proceedings 2021, 68, $\mathrm{x}$,

doi:10.3390/xxxxx

Published: date

Publisher's Note: MDPI stays neutral with regard to jurisdictional claims in published maps and institutional affiliations.

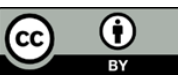

Copyright: (C) 2021 by the authors. Submitted for possible open access publication under the terms and conditions of the Creative Commons Attribution (CC BY) license (http://creativecommons.org/licenses /by/4.0/).

\begin{abstract}
Kashmir valley is located between the Pir-Panjal and the Karakoram Range in the India. The valley is encircled by mountain ranges characterized by snow covered high mountain peaks. Kashmir is known for its scenic beauty throughout the world named as "paradise on earth." One of the main factors backing to this fame of Kashmir is its rich biodiversity corresponding with a wide variety of habitats. Agricultural growth is essential for any region to alleviate rural poverty, ensure food security and create job opportunities for people living in rural and urban areas. Traditionally, agriculture has been practicable and sustainable industry in the Kashmir. By tradition it has been the predominant sector in the Kashmir valley which supports around above 70 per cent of its population directly or indirectly is associated with agriculture and allied activities. The important features like topography, physiographic feature, diversity of habitat especially Karewas and elevation are the key elements which creates the difference between hill and plain areas. Hilly areas as generally offer a vast scope for the growers and cultivation of mixed crops like, cereals, pulses, oilseeds, Saffron, maize, vegetables. The most important and dominant feature of hill farming is the small holding, sloping marginal lands. This region has its own specific geo-climatic condition, which determine the cropping pattern and its productivity allied activities like horticulture, dairy development, fisheries, livestock and sericulture also play significant role in the agriculture sector.
\end{abstract}

Keywords: Agriculture, allied sectors, Cereals, Oilseeds, mountains, Tradition, Farming

\section{Introduction}

Agriculture is the most important industry of the people of Jammu \& Kashmir. Even though, others who are engaged in other sectors also depend on agriculture for raw material (Majeed et al., 2021). The state is occupied mostly by mountainous part in which about only $30 \%$ of the reporting area is under cultivation (Romshoo et al., 2020). The hilly and mountain areas differ from plains in topography, elevation and physiographic diversity of habitats for flora and fauna. The hilly areas are generally grown with grass, herbs, shrubs, maize, pulses and wheat to some extent (Jee 2020). Agricultural crops like rice, wheat, pulses, oil seeds,

vegetables are grown in plains of valley. Agricultural growth is important for any region to alleviate rural poverty, ensure food security and create job opportunities for people living in rural and urban areas (Dev et. 
al., 2010). Kashmir valley is a NW-SE oriented elongated trough located in northwest. Kashmir valley witnessed drastic land use and land cover changes mainly as a result of increase in population size, economic growth, changes in agriculture practices, and execution of different development projects particularly during last three decades (Alam et al., 2020). Agriculture has been predominant sector in this region, providing support to majority of the population. Agricultural growth is essential for any region to alleviate rural poverty, ensure food security and create job opportunities for people living in rural and urban areas Agriculture is the mainstay of our economy as about $70 \%$ of the population directly or indirectly is associated with agriculture and allied activities (Ahmad and Farooq 2010). The state Jammu and Kashmir is fundamentally divided into two divisions namely as Jammu division and Kashmir division and each division having their own and distinct geographical outlook for their respective agro climatic zones which in turn determine their cropping pattern and productivity of crops(Dar et. al., 2020). Jammu and Kashmir is well known for its Paddy crop followed by maize, oilseeds, pulses, vegetables fodder and wheat whereas in Jammu region the most grown and eatable crop is wheat which is followed by maize, paddy, pulses, oilseeds, pseudocereals etc (Sheikh and Singh 2013). Jammu and Kashmir has also got the monopoly in terms of Saffron crop (famous all over the world due to its quality) which has been produced in district Pulwama which is $15 \mathrm{~km}$ distant from Srinagar (Husaini 2014). The cropping pattern of a region reveals the proportion of area of land under different crops at a point of time, the rotation of crops and the area under double cropping (Ganaie et al., 2019). The cropping pattern changes in space and time. In fact, no cropping pattern can be good and ideal for all times to come. Cropping system is based on the climatic, soil and the water availability has to be evolved for realizing the potential production levels through efficient use of available resources. (Batool et. al.,2019) The main aim of the cropping pattern system is to provide enough food for the family, fodder for the cattle and generate sufficient cash income for demotic and cultivation expenses (Kaloo et.al., 2015) The aim of the present study is to document the Agricultural crops that are gowning in the valley for food, fodder and other purposes.

\section{Study area}

Kashmir Himalaya is youngest mountain range owning a dramatic landscape with snow, glaciers gushing drainage basin extending between the Pirpanjal and the Zanskar range. The region falls within the biogeographic province in the northwestern Himalayas, lies between $33^{\circ} 20^{\prime}$ to $34^{\circ} 54^{\prime} \mathrm{N}$ and $73^{\circ} 55^{\prime}$ to $75^{\circ} 35^{\prime} \mathrm{E}$, 
covering an area of $15948 \mathrm{~km}^{2}$ and represents an exclusive biospheric unit (Rodgers and Panwar 1988). The altitude of the valley ranges from 1,600 $\mathrm{m}$ to 5,420 $\mathrm{m}$ (asl). Topographically, the valley depicts an elliptical bowl-shaped character, bounded by mighty Pir-Panjal range in its south and southwest and the greater Himalayan range in the north and northeast (Romshoo et al., 2020). Within the Himalayas, the Kashmir valley has a discrete geographical and distinct physiographic personality. The valley can be divided into four broad physiographic divisions: the mountains, the foot hills, the Karewas and the valley. Climate of the region is distinct by well-defined seasonality, during summer the temperature ranges from an average daily maximum of $31^{\circ} \mathrm{C}$ and minimum of $15^{\circ} \mathrm{C}$ to $4^{\circ} \mathrm{C}$ max. $\&-4^{\circ} \mathrm{C}$ min. during winter. The valley causes precipitation mostly in the form of snow, receives annual precipitation of about 1,050 $\mathrm{mm}$. Because of heterogeneous edapho-climatic and physiographic range including lakes, springs, swamps, orchards, subalpine and alpine meadows, montane slopes and terraces, permanent glaciers etc. (Gupta 1982; Singh et al., 1998). The Kashmir valley consists of ten districts such as Budgam, Bandipora, Anantnag, Baramulla, Ganderbal, Kulgam, Pulwama, Kupwara, Shopian and Srinagar district.

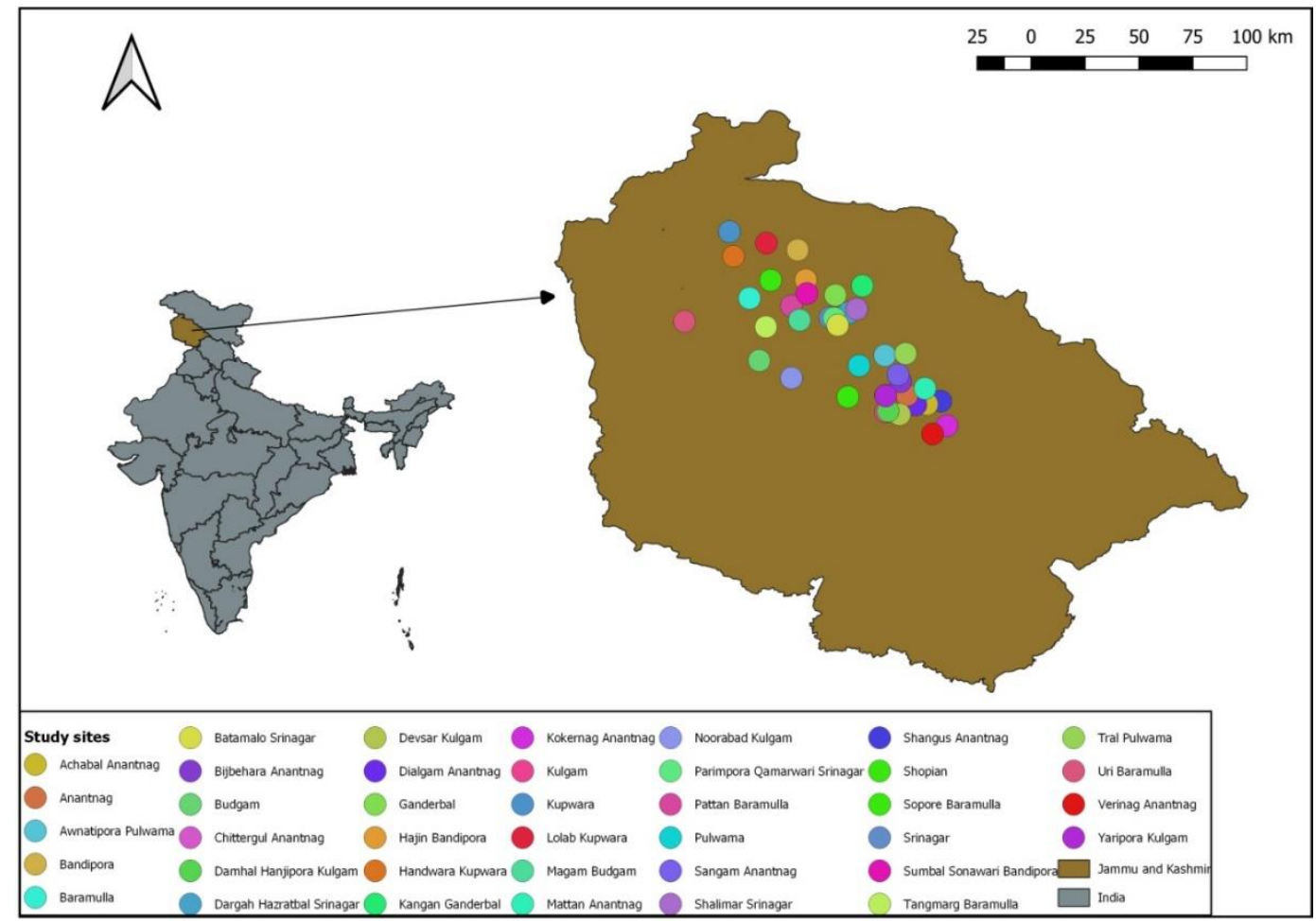

Fig. 1. Map showing selected study sites. 


\section{Materials and Methods}

During the year 2016-2017, field surveys were carried out in different areas (Fig.1) of Kashmir valley to assess the different parameters (growing season, number of crops etc.) related to different agricultural crops of Kashmir valley. During the field survey various parameters such as habit, fruit type etc. were recorded in field. The part/parts of the crops used for consumption was recorded by interaction with local people. Market surveys were carried out in the market and the information about edible parts of commercially important crops was documented also the peak availability of certain vegetable were assessed. The SKUAST-K and many off-field stations were visited for the data collection pertaining to the current study. Native geographical range of the plant species has been obtained from all possible available sources; native geographical range of the plant species has been obtained from all possible available sources (Randall 2002), including the specialized Internet web pages (POWO 2020) and recently published similar works. Following Pysek et al. (2002), we recognized the origin of the species at the continental scale viz., Asia (excluding Indian subcontinent), Europe, Africa, North America, Southern America, and Australia.

\section{Results}

This work helps to understand the types of crops, life span, nativity etc. of various agricultural crops growing in Kashmir valley. It also includes an analysis of different parameters related various agriculture crops. Inventory of agricultural biodiversity in Kashmir valley (botanical name, vernacular name, flowering/fruiting, fruit type and nativity) has been prepared as shown in table 1. Present inventorization reveals that the agricultural crops of Kashmir comprised of 75 plant species belonging to 52 genera and 18 families. Largest number of plant species belongs to families of Leguminaceae (18) followed by Brassicaceae (9). The genus with highest number of species is Brassica followed by Amaranthus. Number of crop species belongs to different families and their life span is shown in Figs. $2 \& 3$ respectively. Our results showing the highest number of crop species belongs to family Leguminaceae (Fabaceae). Our results also showing the part/parts used for food/fodder by people. Most palatable part is seed and least is inflorescence as shown in Fig. 4. Type of studied crops on the basis of sowing and harvesting period are shown in Fig. 5, revealed that Kharif crops comprises of 45, rabi with 12 and zaid with 7 crop species. Nativity and types of fruits of studied crop species are shown in Fig. 6 \& 7 respectively, depicts that Europe is native region of highest number of agriculture crop species and pod (legume) is the prominent fruit type. 
Table1: Conspectus of the Agricultural of Kashmir.

\begin{tabular}{|c|c|c|c|c|c|c|}
\hline Plant Name & Common name & Family & Life cycle & Part/parts used & Crop type & Nativity \\
\hline Abelmoschus esculentus (L.) Moench & Bhindi & Malvaceae & Annual & Fruit & Kharif & Native \\
\hline Allium cepa var. aggregatum G.Don & Ganda & Amaryllidaceae & Annual & Stem & Kharif & Africa, Europe \\
\hline Allium sativum $\mathrm{L}$ & Rohan & Amaryllidaceae & Annual & Stem & Kharif & Central Aisa \\
\hline Amaranthus blitum $\mathrm{L}$. & Ganhar/ lissa & Amaranthaceae & Annual & Leaves & Kharif & Southern America \\
\hline Amaranthus caudatus L. & do & Amaranthaceae & Annual & Leaves & Kharif & Southern America \\
\hline Amaranthus hybridus $\mathrm{L}$. & do & Amaranthaceae & Annual & Leaves & Kharif & Northern America \\
\hline Amaranthus hypochondriacus $\mathrm{L}$. & do & Amaranthaceae & Annual & Leaves & Kharif & Southern America \\
\hline Atriplex hortensis L. & Wasta-haak & Chenopodiaceae & Annual & Leaves & Kharif & Europe \\
\hline Avena byzantina $\mathrm{K}$. Koch & Khasel & Poaceae & Annual & Whole plant & Others & Turkey \\
\hline Beta vulgaris $\mathrm{L}$. & Chokander & Amaranthaceae & Annual & Root and leaves & Kharif & Europe \\
\hline Brassica oleracea L. Var fimbriata & Multani/Arbi-Haak & Brassicaceae & Annual & Leaves & Kharif & Europe \\
\hline Brassica oleracea var. acephala DC. & Khanyari haak & Brassicaceae & Biennial & Leaves & Kharif & Native \\
\hline Brassica oleracea var. botrytis L. & Phhol gobi & Brassicaceae & Biennial & Inflorescence & Kharif & China \\
\hline Brassica oleracea var. capitata $\mathrm{L}$. & Bandh Gobi & Brassicaceae & Biennial & Leaves & Kharif & China \\
\hline Brassica oleracea var. gongylodes L. & Kholrabi & Brassicaceae & Biennial & Leaves & Kharif & China \\
\hline Brassica oleracea var. kashmiriana Naqshi \& Javeid & Hanz-Haak & Brassicaceae & Biennial & Leaves & Kharif & Native \\
\hline Brassica rapa subsp. campestris (L) A.R.Clapham & Tilgogal & Brassicaceae & Biennial & Seeds and leaves & Kharif & \\
\hline Brassica. rapa (Linn) Var. rapa & do & Brassicaceae & Biennial & Seed & Rabi & Italy \\
\hline Cajanus cajan (Linn) Mill. & Arhar & Leguminaceae & Annual & Whole plant & Rabi & Native \\
\hline Capsicum aпnиит $\mathrm{L}$. & Punjaeb martswangun & Solanaceae & Annual & Fruit & Kharif & Northern America \\
\hline Capsicum fructescens $\mathrm{L}$. & Kashur -Martswangun & Solanaceae & Annual & Fruit & Kharif & Northern America \\
\hline
\end{tabular}




\begin{tabular}{|c|c|c|c|c|c|c|}
\hline Celosia argentea (Lin) Var. cristata Kuntze & Moual & Amaranthaceae & Annual & Seed & Others & Native \\
\hline Chenopodium album $\mathrm{L}$. & do & Chenopodiaceae & Annual & Whole plant & Others & Europe \\
\hline Coriandrum sativum $\mathrm{L}$. & Daniwal & Apiaceae & Annual & Leaves and fruit & Kharif & Europe \\
\hline Crocus sativus $\mathrm{L}$. & Kong & Iridaceae & Annual & Flower & Kharif & Europe \\
\hline Cucumis sativus $\mathrm{L}$. & Laer & Cucurbitaceae & Annual & Fruit & Zaid & Native \\
\hline Cucurbita maxima Duchesne & Gol-all & Cucurbitaceae & Annual & Fruit & Zaid & Southern America \\
\hline Cucurbita moschata Duchesne & Kashir all & Cucurbitaceae & Annual & Fruit & Zaid & Mexico \\
\hline Cuminum cyminum $\mathrm{L}$. & Zuir & Apiaceae & Annual & Seed & Kharif & Europe \\
\hline Daucus carota subsp. sativus (Hoffm.) Arcang. & Gazzer & Apiaceae & Annual & Root and leaves & Kharif & Africa, Europe \\
\hline Fagopyrum esculentum Moench & Trumb & Polygonaceae & Annual & Whole plant & Rabi & Europe \\
\hline Fagopyrum kashmirianum A.H.Munshi & do & Polygonaceae & Annual & Whole plant & Rabi & Native \\
\hline Fagopyrum tataricum $(\mathrm{L}$.$) Gaertn.$ & do & Polygonaceae & Annual & Whole plant & Rabi & East Aisa, Europe \\
\hline Foeniculum vulgare Mill. & Badiyan & Apiaceae & Annual & Seed & Kharif & Europe \\
\hline Glycine $\max$ (Linn) Merrill & Gabi muth & Leguminaceae & Annual & Seed & Kharif & China \\
\hline Helianthus annuиs $\mathrm{L}$. & Gule aftaab & Asteraceae & Annual & Seed & Kharif & Northern America \\
\hline Hordeum vulgare $\mathrm{L}$. & Wushka & Poaceae & Annual & Fruit & Rabi & Native \\
\hline Hydrocharis dubia (Blume) Backer & Bumai posh & Hydrocharitaceae & Perennial & Leaves & Others & Europe \\
\hline Lagenaria siceraria (Molina) Standl. & Aal & Cucurbitaceae & Annual & Fruit & Zaid & Africa \\
\hline Lathyrus odoratus L. & do & Leguminaceae & Annual & Seed & Rabi & Europe \\
\hline Lens culinaris Medic. & do & Leguminaceae & Annual & Seed & Rabi & Aisa \\
\hline Linum usitatissimum $\mathrm{L}$. & Masur & Linaceae & Annual & Seed & Rabi & Africa, Europe \\
\hline Luffa cylindrica (L.) Roem. & Tarela & Cucurbitaceae & Annual & Fruit & Zaid & Europe \\
\hline Lycopersicon esculentum Mill & Ruwangun & Solanaceae & Annual & Fruit & Zaid & Southern America \\
\hline Malva sylvestris $\mathrm{L}$. & Baghe sostal & Malvaceae & Annual & Leaves & Kharif & Europe \\
\hline Malva verticillata $L$. & do & Malvaceae & Annual & Leaves & Kharif & Europe \\
\hline Medicago sativa $\mathrm{L}$. & Luecurene & Leguminosae & Perennial & Whole plant & Others & Africa, Europe \\
\hline Melilotus indica (L.). All & do & Leguminosae & Perennial & Whole plant & Others & Africa, Europe \\
\hline
\end{tabular}




\begin{tabular}{|c|c|c|c|c|c|c|}
\hline Mentha $x$ piperita $\mathrm{L}$ & Pudna & Malvaceae & Annual & Leaves & Kharif & Africa,Europe \\
\hline Momordica charantia L. & Karela & Cucurbitaceae & Annual & Fruit & Zaid & Africa, Europe \\
\hline Nelumbo nucifera Gaertn. & Nadur & Nelumbonaceae & Perennial & Stem & Others & Africa, East Aisa \\
\hline Nymphaea alba $\mathrm{L}$. & do & Nymphaeaceae & Perennial & Leaves and fruit & Others & Native \\
\hline Oryza sativa $\mathrm{L}$. & Dhani & Poaceae & Annual & Fruit & Kharif & China \\
\hline Panicum miliaceum $\mathrm{L}$. & Pingha & Poaceae & Annual & Seed & Kharif & Africa, Europe \\
\hline Papaver somniferum $\mathrm{L}$. & Kash kash & Papaveraceae & Annual & Seed & Kharif & Europe \\
\hline Phaseolus lunatus L. & Subaz Razma & Leguminaceae & Annual & Seed & Kharif & Central America \\
\hline Phaseolus vulgaris $\mathrm{L}$. & Farsh beans & Leguminaceae & Annual & Seed & Kharif & Southern America \\
\hline Pisum sativum $\mathrm{L}$. & Matar/ Kare & Leguminaceae & Annual & Seed & Kharif & Africa \\
\hline Raphanus sativus $\mathrm{L}$. & Muj & Brassicaceae & Biennial & Root/Leaves & Rabi & Africa, Europe \\
\hline Setaria italica (L.) P.Beauv. & Shol & Poaceae & Annual & Seed & Kharif & Africa \\
\hline Solanum melongena $\mathrm{L}$. & Wangun & Solanaceae & Annual & Fruit & Kharif & Aisa \\
\hline Solanum tuberosum $\mathrm{L}$. & Aalou & Solanaceae & Annual & Stem & Rabi & Southern America \\
\hline Spinacia oleracea $\mathrm{L}$. & Palak & Amaranthaceae & Annual & Leaves & Kharif & Aisa \\
\hline Trachyspermum ammi (L.) Sprague & do & Apiaceae & Annual & Seed & Kharif & Southern America \\
\hline Trifolium alexandrinum $\mathrm{L}$. & Berseem & Leguminaceae & Perennial & Whole plant & Others & Africa, Europe \\
\hline Trifolium fragiferum $\mathrm{L}$. & do & Leguminaceae & Perennial & Whole plant & Others & Africa, Europe \\
\hline Trifolium pratense $\mathrm{L}$. & Posh Gase & Leguminaceae & Perennial & Whole plant & Others & Africa, Europe \\
\hline Trigonella foenum graecum L. & Meth & Leguminacaeae & Annual & Seed & Kharif & Africa, Europe \\
\hline Triticum aestivum $\mathrm{L}$. & Kanak & Poaceae & Annual & Fruit & Rabi & Africa, Europe \\
\hline Vicia faba $\mathrm{L}$. & Bagla & Leguminaceae & Annual & Seed & Kharif & Africa, Europe \\
\hline Vigna aconitifolia (Jacq.) Marechal & Muth & Leguminaceae & Annual & Seed & Kharif & Native \\
\hline Vigna mungo (Linn.) Hepper & Maha/Urd & Leguminaceae & Annual & Seed & Kharif & Native \\
\hline Vigna radiata (L.) R.Wilczek & Mong & Leguminaceae & Annual & Seed & Kharif & Native \\
\hline Vigna unguiculata (L.) Walp. Subsp. Sesquipedalis & Asparug & Leguminaceae & Annual & Seed & Kharif & Africa \\
\hline Zea mays $\mathrm{L}$. & Makai & Poaceae & Annual & Fruit & Kharif & Southern America \\
\hline
\end{tabular}




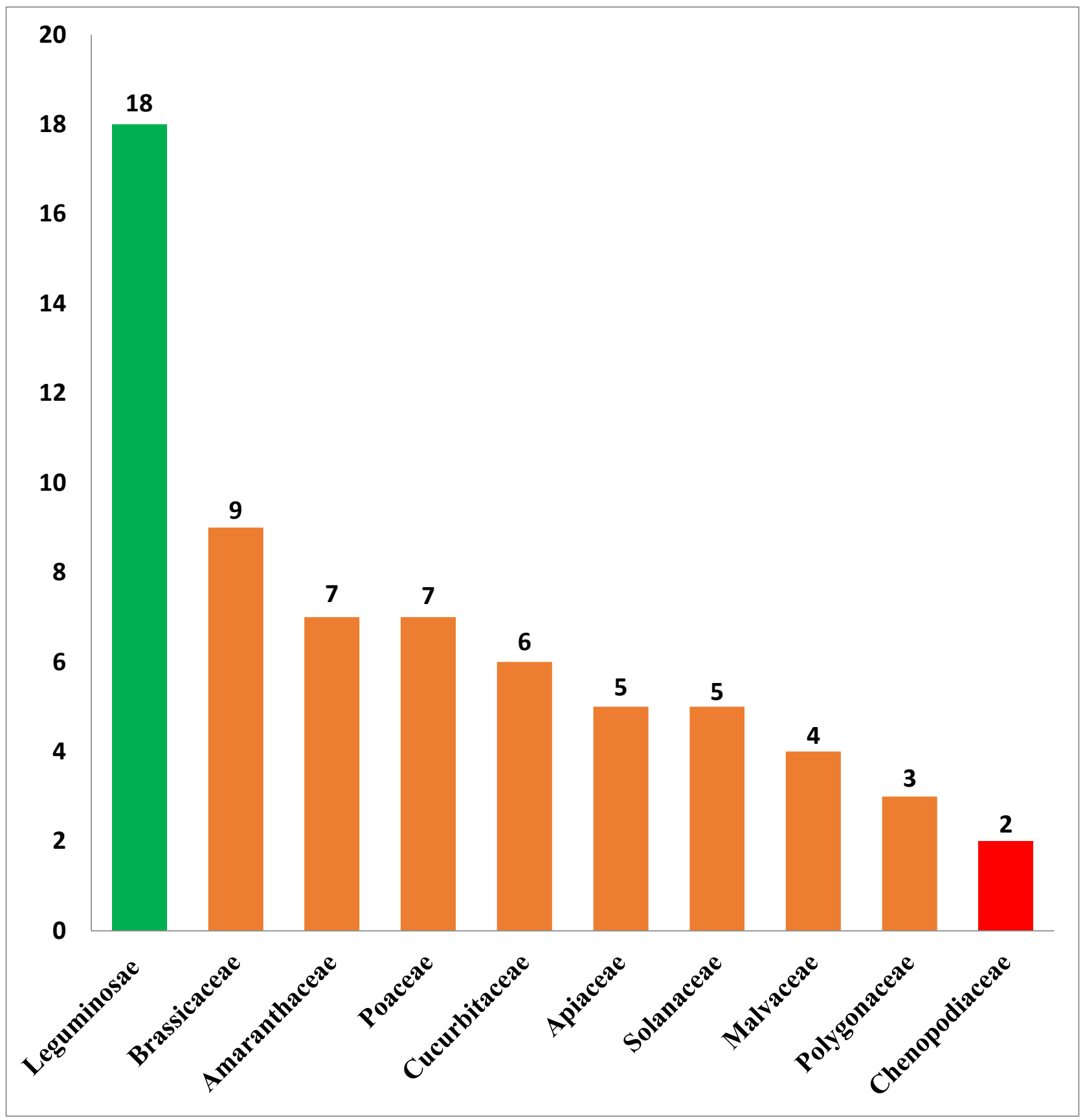

Fig. 2. Bar diagram showing number of species belonging to different families growing as an agriculture crop. 


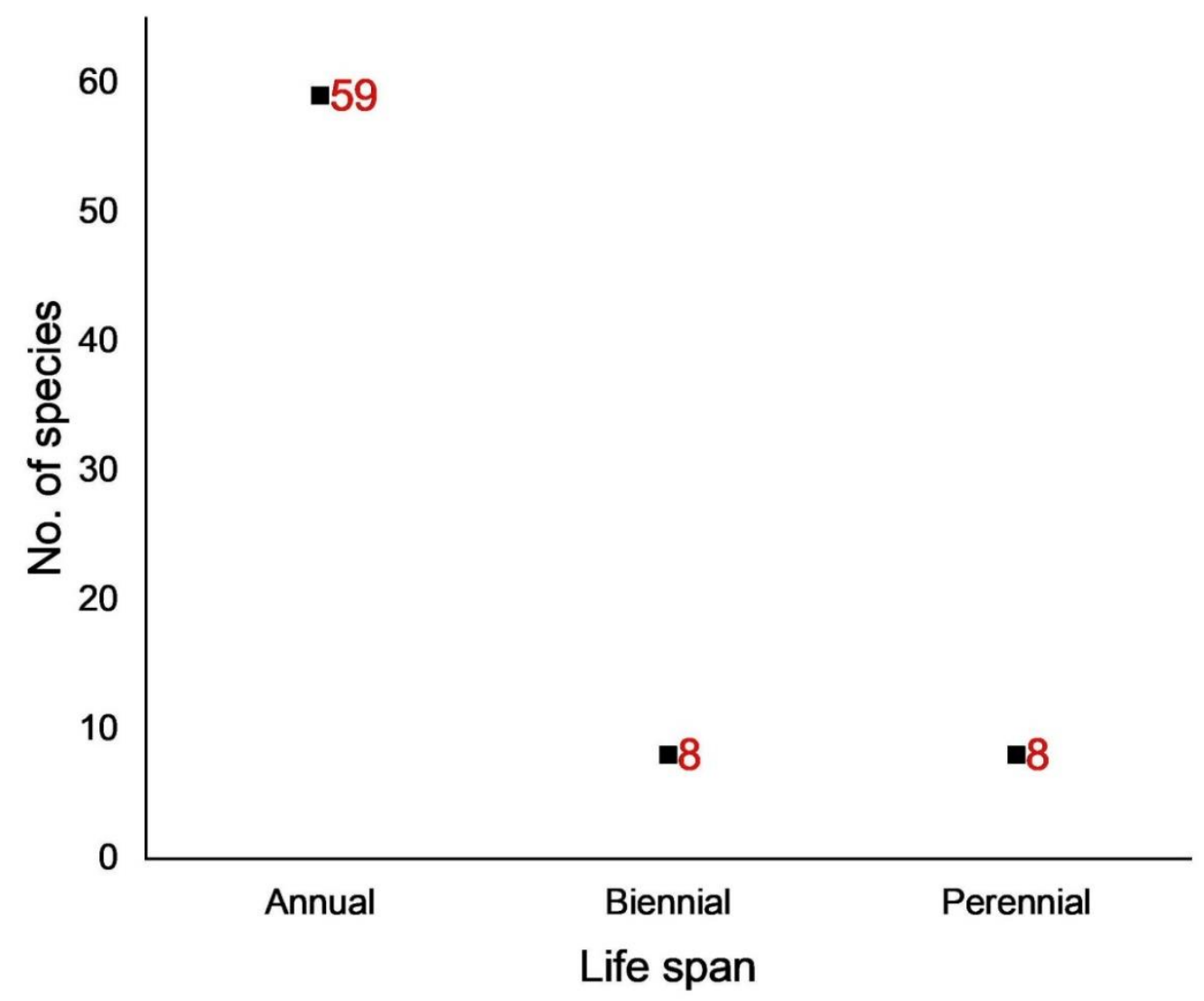

Fig. 3. Life span of various agriculture crops in Kashmir valley.

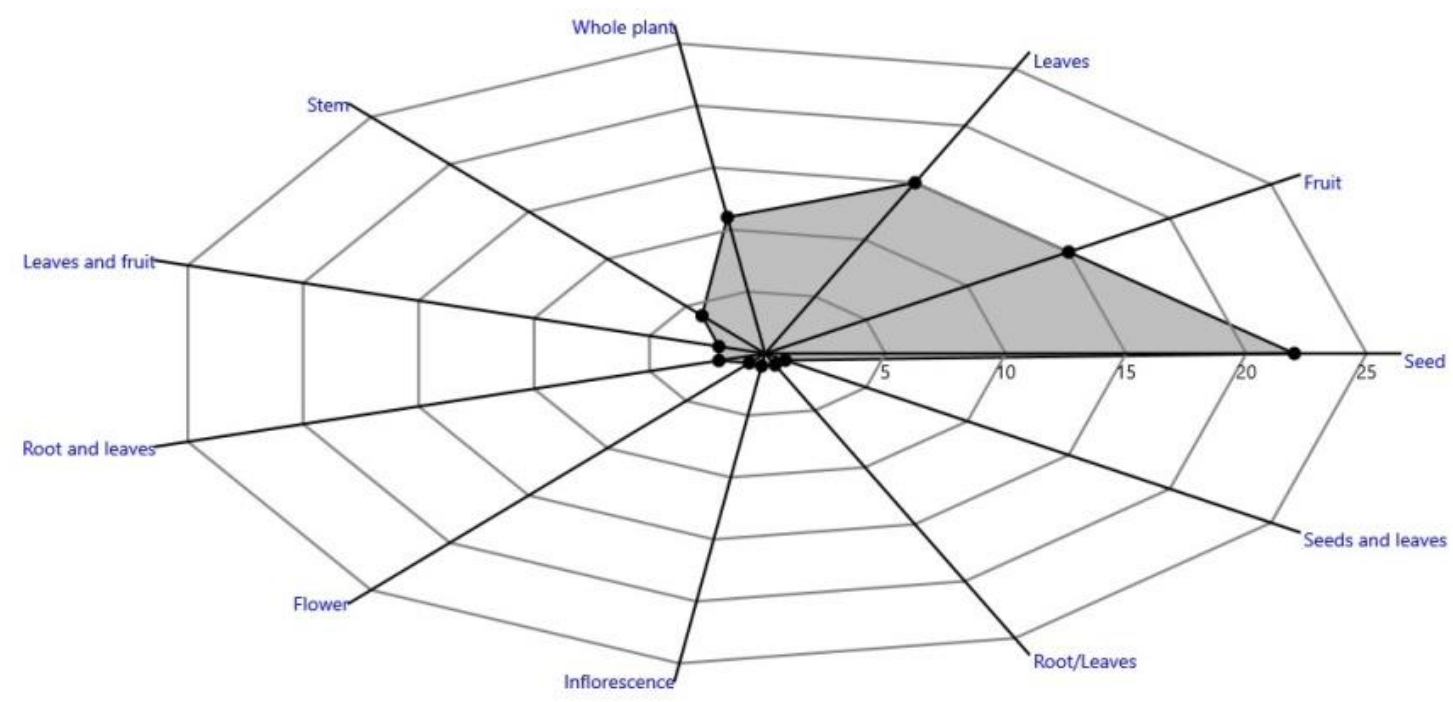


Fig.4. Radar chart showing the parts used for food/fodder.

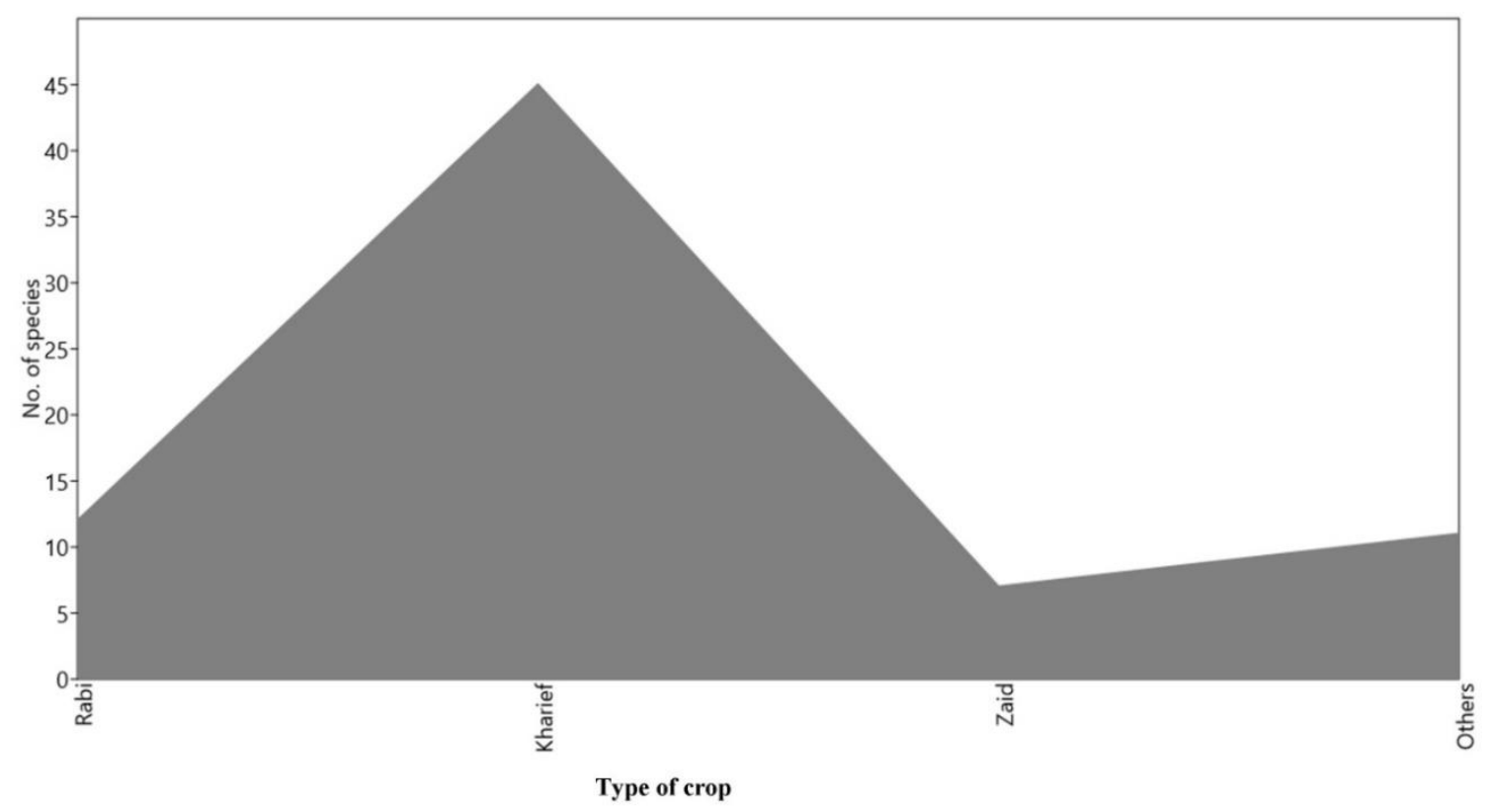

Fig. 5. Line filled plot showing types of different agricultural crops based on their sowing and harvest.

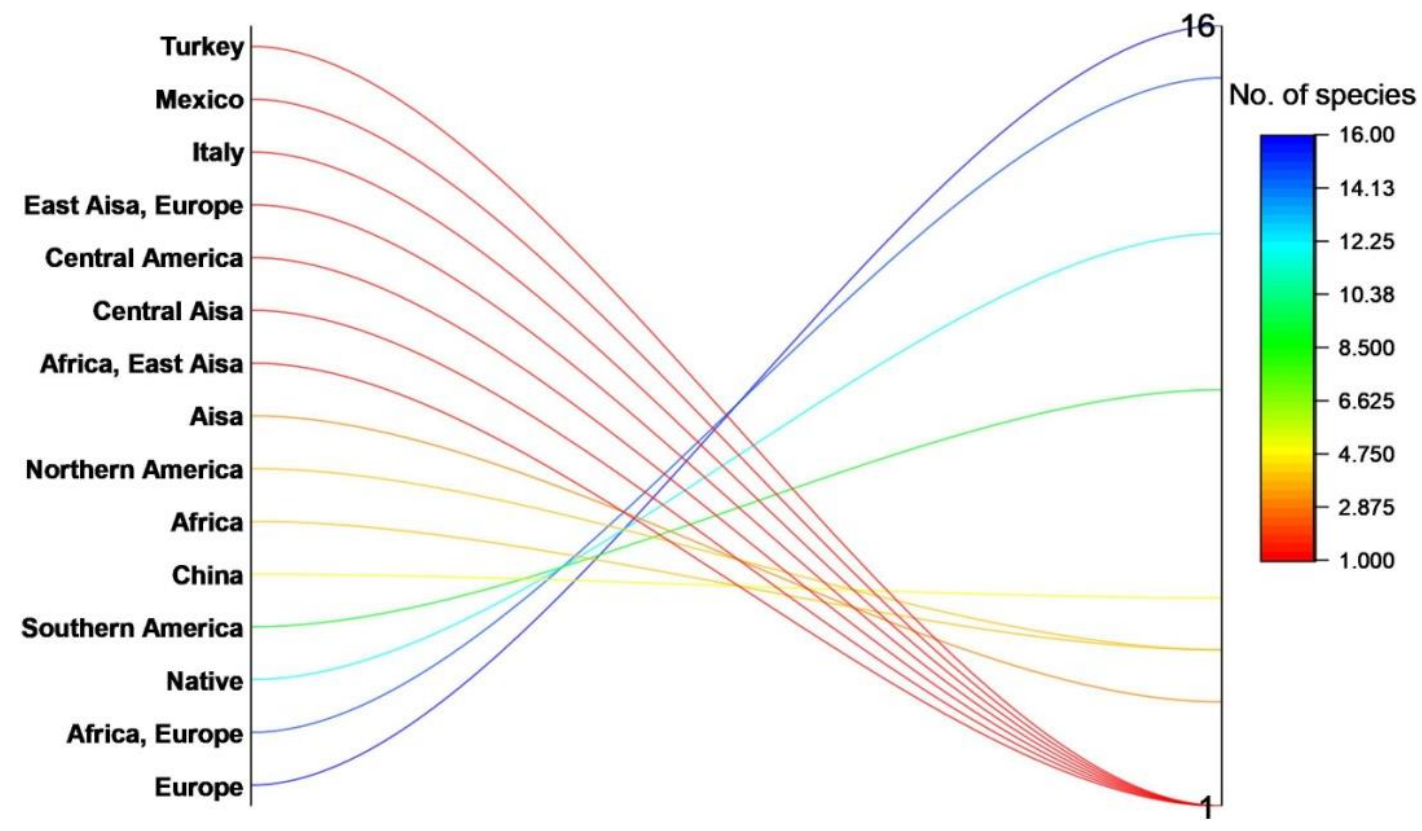

Nativity

No. of species 
Fig. 6. Parallel plot showing the nativity of different agricultural crops growing in Kashmir valley.

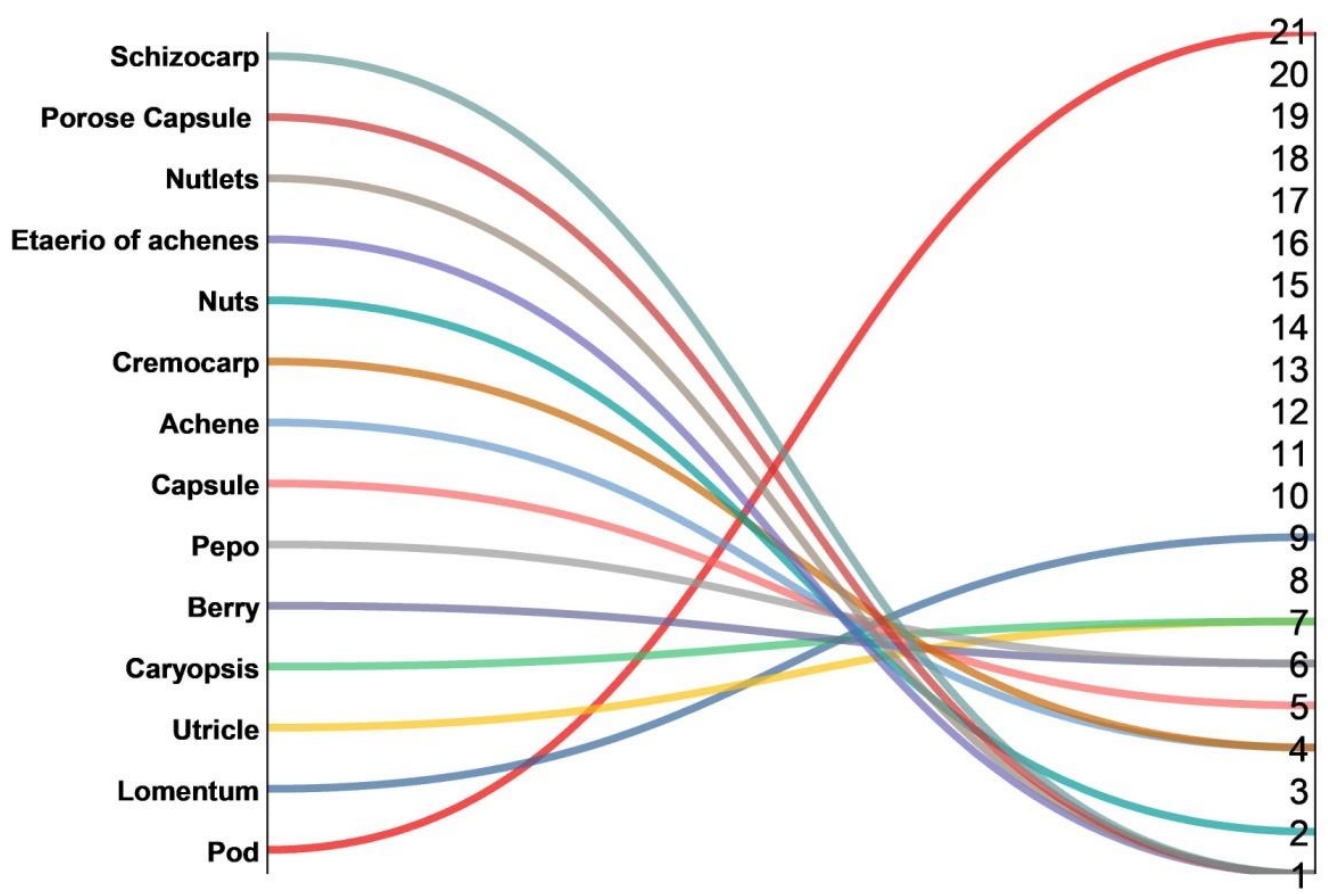

Type of fruit

No. of species

Fig. 7. Parallel plot showing various types of fruits produced from different agricultural crops.

\section{Discussion}

The production of three important food crops, namely, rice, maize and wheat contributes a major portion of the food grains in the Kashmir valley. Kashmir region has also got the monopoly in terms of Saffron crop (famous all over the world due to its quality) (Bhat et al., 2017). Although the cropping activity goes on throughout the year in some districts but there are two distinct seasons i.e. Kharif season and Rabi season. Kharif season related to rainfall, if it is good the crop response will be good on the other hand if the rainfall is unfavorable the crop response will be poor e.g., rice, maize, pulses and fodder (Chappell et. al., 2007, Singh et al., 2020). The rabi season is marked with the onset of winter which is marked with the temperature starts coming down. Irrigation plays a very important role in this season. In rabi season when the temperature is relatively low the crops grown in this region are wheat, pulses (gram, peas, masur), fodder, 
mustard, potato and other vegetables (Maqbool 2013). Kashmir is one of the major saffron producing regions of the world. Crown in the Karewas of Kashmir it is an important cash crop providing employment to about 5 per cent of the total rural workforce in Valley of Kashmir (Ganaie et al., 2019). This valuable "golden" spice is known as "Kum Kum" and "Kesar" in Sanskrit and "Koung" in Kashmiri language. At present, the crop is being cultivated in some areas of adjoining districts like Srinagar, Ganderbal, Budgam, Shopian, Anantnag, Bhaderwah and Kulgam. But, still the main hub of Saffron cultivation is considered as Pampore area of district Pulwama (Ganaie et al., 2019).

\section{Conclusion}

To sustain continuous growth in productivity in agriculture, profitability and sustainability is must. There is a need to create general awareness techniques to enhance production, productivity and quality of food grains. This study helps to understand the various characteristics of agricultural crops growing in Kashmir valley. The significant crops important crops are Rice, maize, wheat, barley, pulses etc. Different agricultural crops with their life span, part/parts used are assessed in present study. Kashmir region has also got the monopoly in terms of Saffron crop (famous all over the world due to its quality) which has been produced in the Pampore (Pulwama) and Budgam district. Although the cropping activity goes on throughout the year in some districts but there are two distinct seasons. Kharif season related to rainfall, if it is plentitude the crop response and yield will be good, on the other hand if the rainfall is unfavorable the crop response will be poor. However, the rabi season is marked with the onset of winter.

\section{Acknowledgements}

Authors are grateful to Department of Botany, University of Kashmir for providing better facilities to conduct this study. Authors are also highly thankful to all the colleagues who provided the valuable comments about the manuscript.

\section{Competing interest}

Authors declare that no competing interest exists. 


\section{References}

1. Ahmad, M., \& Farooq, U. (2010). The state of food security in Pakistan: Future challenges and coping strategies. The Pakistan Development Review, 903-923.

2. Ahmad, S., Bhat, M. I., Madden, C., \& Bali, B. S. (2014). Geomorphic analysis reveals active tectonic deformation on the eastern flank of the Pir Panjal Range, Kashmir Valley, India. Arabian Journal of Geosciences, 7(6), 2225-2235.

3. Akhtar, R., \& Acharya, R. (2015). Changes in cropping pattern in Jammu and Kashmir. International Journal of Advanced Research in Education \& Technology (IJARET), 2(4).

4. Alam, A., Bhat, M. S., \& Maheen, M. (2020). Using Landsat satellite data for assessing the land use and land cover change in Kashmir valley. GeoJournal, 85(6), 1529-1543.

5. Baba, S. H., Wani, M. H., \& Zargar, B. A. (2011). Dynamics and sustainability of livestock sector in Jammu \& Kashmir. Agricultural Economics Research Review, 24(347-2016-16887), 119-132.

6. Batool, N., Shah, S. A., Dar, S. N., \& Skinder, S. (2019). Rainfall variability and dynamics of cropping pattern in Kashmir Himalayas: a case study of climate change and agriculture. SN Applied Sciences, 1(6), 1-9.

7. Bhat, M. M. (2013). Agricultural land-use pattern in Pulwama district of Kashmir Valley. International Journal of Economics, Business and Finance, 1(5), 80-93.

8. Bhat, T. A., \& Lone, T. A. (2017). Potential and Prospects of J\&K Economy. Educreation Publishing.

9. Bhushan, A., Kumar, S., Sharma, S., Sharma, V., Kumar, M., \& Bali, K. (2020). Seed Production of Knolkhol (Brassica oleracea var. Gongylodes) under Mid Hills of Jammu \& Kashmir, India. Int. J. Curr. Microbiol. App. Sci, 9(8), 521-525. 
10. Chappell, M. J. (2007). “Shattering Myths: Can Sustainable Agriculture feed the world?”, Institute for Food and Development Policy, Vol. 13, Issue 3, pp. 1-4.

11. Dar, G. H., \& Khuroo, A. A. (2020). An introduction to biodiversity of the Himalaya: Jammu And Kashmir State. In Biodiversity of the Himalaya: Jammu and Kashmir State (pp. 3-26). Springer, Singapore.

12. Dev, S. M., \& Sharma, A. N. (2010). Food security in India: Performance, challenges and policies.

13. Ganaie, D. B., \& Singh, Y. (2019). Saffron in Jammu \& Kashmir. Int. J. Res. Geogr, 5, 1-12

14. Gupta, R. K. (1982). Mediterranean influence in the flora of Western Himalaya. In: Paliwal GS (ed) The vegetational wealth of the Himalayas. Puja Publishers, New Delhi, India, pp.175-193.

15. Husaini, A. M. (2014). Challenges of climate change: Omics-based biology of saffron plants and organic agricultural biotechnology for sustainable saffron production. GM crops \& food, 5(2), 97-105.

16. Jee, V. (2020). Vegetation of Jammu and Kashmir State: A General Account. In Biodiversity of the Himalaya: Jammu and Kashmir State (pp. 167-190). Springer, Singapore.

17. Kaloo, M. J., \& Choure, T. (2015). Present status and future prospectus of agriculture in Jammu and Kashmir. IOSR-JHSS, 20(11), 62-67.

18. Majeed, M., \& Bhat, G. M. (2021). MGNREGA and Agriculture in Kashmir Valley: A Case Study of District Budgam. Asian Journal of Economics, Business and Accounting, 121-129.

19. Mehmood, Y., \& Kumar, P. (2020). Status of Agriculture Production and Productivity in Jammu and Kashmir. Available at SSRN 3643764.

20. Pyšek, P., Sádlo, J., \& Mandák, B. (2002). Catalogue of alien plants of the Czech Republic. Preslia, 74(2), 97-186.

21. Randall, R. P. (2017). A global compendium of weeds (No. Ed. 3). RP Randall.

22. Rodgers, W. A., \& Panwar, H. S. (1988). Biogeographical classification of India. Wildlife Institute of India, Dehradun, India.

23. Romshoo, S. A., Rashid, I., Altaf, S., \& Dar, G. H. (2020). Jammu and Kashmir state: an overview. Biodiversity of the Himalaya: Jammu and Kashmir State, 129-166.

24. Sheikh, S. M., \& Singh, O. (2013). Pseudocereals and millets: the lost crops of Kashmir. Genetic resources and crop evolution, 60(3), 1191-1199. 
25. Singh, D. K., Uniyal, B. P., \& Mathur, R. (1998). Jammu and Kashmir. In: Singh NP, Singh DK (eds) Floristic diversity and conservation strategies in India. Botanical Survey of India, Kolkata, India. pp. 904-973.

26. Singh, S., Singh, N., \& Pandey, Y. (2020). Water Productivity of Vegetables Crop under Temperate Condition of Kashmir Valley. Int. J. Curr. Microbiol. App. Sci, 9(7), 3152-3168. 